\title{
THE DIVERSITY OF INSECT VISITORS ON INDONESIAN SALACCA (SALACCA SPP.) IN MEKARSARI FRUITS GARDEN, BOGOR, INDONESIA
}

\author{
Tri Atmowidi ${ }^{1}$, Sih Kahono ${ }^{2}$, Dorly ${ }^{1}$, Suci Dwi Rahmawati ${ }^{1}$, Delbert Reinaldo ${ }^{1}$, \\ Eris Safiril Ummah ${ }^{1}$

\footnotetext{
${ }^{1}$ Department of Biology, Faculty of Mathematics and Natural Science, Bogor Agricultural University (IPB University), Bogor, Indonesia 16680

${ }^{2}$ Laboratory of Entomology, Zoology Division, Research Center for Biology, Indonesian Institute of Sciences (LIPI), Cibinong, Indonesia 16911
}

Link to this article: https://doi.org/10.11118/actaun.2021.024

Received: 1. 12. 2020, Accepted: 18. 3. 2021

To cite this article: ATMOWIDI TRI, KAHONO SIH, DORLY, RAHMAWATI SUCI DWI, REINALDO DELBERT, UMMAH ERIS SAFIRIL. 2021. The Diversity of Insect Visitors on Indonesian Salacca (Salacca Spp.) in Mekarsari Fruits Garden, Bogor, Indonesia. Acta Universitatis Agriculturae et Silviculturae Mendelianae Brunensis, 69(2): 267-273.

\begin{abstract}
Salacca (Salacca spp.) is a dioecious plant with male and female flowers existing on a different plant, therefore requires agents of pollination. More than thirty cultivars of salacca are found in Indonesia. This research aimed to study the diversity of visiting insects on the three varieties of salacca, i.e., Pondoh, Mawar and Kalimantan in Indonesia, as well measuring the pollen load on the pollinators. The visiting insects were observed on the male flowers using the fix sample method in ten minutes for fifteen days. Results showed that nine insect species visited the flowers and three species were potential pollinators, i.e., Nodocnemis sp., Apis cerana and Tetragonula laeviceps. The highest diversity of visiting insects was found in Kalimantan salacca $\left(H^{\prime}=1.31, E=0.74\right)$ followed by Pondoh salacca $\left(H^{\prime}=0.72, E=0.23\right)$ and Mawar salacca $\left(H^{\prime}=0.51, E=0.19\right)$. There was no dominant species found in Kalimantan salacca. The high similarity of visiting insects was found in Pondoh-Mawar salacca (SN = 0.59). Furthermore, the pollen load on Nodocnemis sp., A. cerana and T. laeviceps were about 127, 7893, and 4228 pollen grains, respectively.
\end{abstract}

Keywords: Nodocnemis, pollinator, pollen load, salacca

\section{INTRODUCTION}

Salacca, Salacca zalacca (Gaert.) Voss is an Indonesian native plant with high economic value. Nineteen species of Salacca have been identified (Mogea, 1978) and distributed in southern Yunnan, Burma, Thailand, Malaysia, Sumatra, Java, Borneo, and Philippines (Mogea, 1980). Borneo has the largest number of species (10 species), followed by the Malay Peninsula (7 species) and Sumatra (7 species). The two main species cultivated in Indonesia are S. sumatrana and S. zalacca (Mogea, 1978) and about thirty cultivars are found in Indonesia (Sudaryono and Purnomo, 1993). Two varieties of salacca, i.e., S. zalacca var. zalacca (Pondoh and Mawar salacca) are commonly found in Java and Madura and S. zalacca var. amboinensis (Becc.) Mogea (Bali salacca) are common in Bali (Mogea, 1982). Fruit's texture, color, size, aroma, taste, and habitus are the main characteristics of each variety.

Pondoh salacca is a superior variety compared to others, in that its fruit is sweet, white flesh and crispy in taste (Ashari, 2002). Mawar salacca is 
a breed between Sidempon and Bali salacca and this variety is commonly used as a donor of pollens during manual pollination since it produces a lot of pollens that mature in 2-3 days. Kalimantan salacca, S. affinis (Mogea) distributed in Sumatra, Borneo and Malaysia. It grows in solitary or in small groups (2-3 plants) with male and female flowers of about $3-6 \mathrm{~cm}$ and $5-8 \mathrm{~cm}$ in length, respectively (Gari, 2005). In general, salacca plants are dioecious with male and female inflorescences are found on different plants. However, the Bali salacca are monoecious with male and female flowers are found on the same plant (Schuiling, 1991) and are arranged in the inflorescences (Suskendriyati et al., 2000).

Because the plants are generally dioecious, the pollination is mainly assisted by wind, insects and humans. A previous study showed that the curculionid beetle is a major pollinator of salacca. Other insects that visited the salacca flowers are stingless bees (Apidae: Hymenoptera) and beetle, Rhynchophora palmarum L. (Coleoptera). The latest beetle species was reported as a pest that damages the flowers (Mogea, 1978). Curculionid beetle, Nodocnemis sp. (Coleoptera: Curculionidae) is the main pollinator of Pondoh salacca in Sleman, Yogyakarta (Wagiman et al., 2014). The beetle species also was reported as the main pollinator of Sumatra salacca (S. sumatrana Becc.) (Tanjung et al., 2019). Before this time, the publications on pollinating insects of salacca were limited. This research aimed to study the diversity of visiting insects on the three varieties of salacca, i.e., Pondoh, Mawar and Kalimantan found in Indonesia, as well as measuring the pollen load on the pollinators.

\section{MATERIALS AND METHODS}

\section{Study Site}

This study was conducted in Mekarsari Fruit Garden (MFG), Bogor, Indonesia as a center for the preservation of tropical fruits as well as vegetables and flowers and ornamental plants as a source

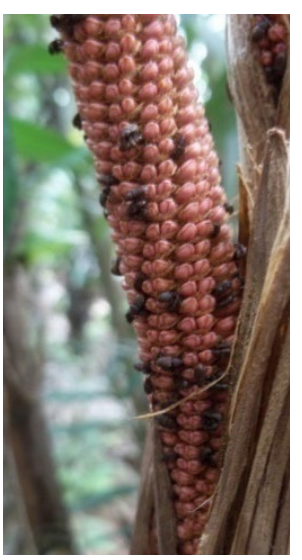

$1 \mathrm{a}$

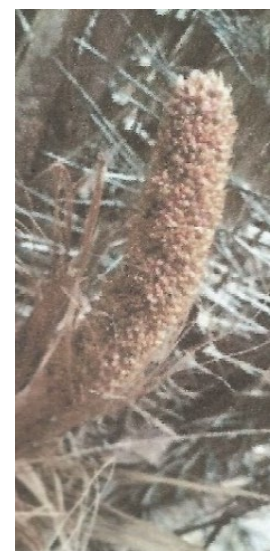

$1 \mathrm{~b}$ of germplasm in Indonesia. This garden also functions as a recreation park. MFG collected six species of salacca, i.e., Salacca zalacca, S. sumatrana, S. wallichiana, S. affinis, S. magnifica, and S. glabrescens. In this study, we used S. zalacca (var. pondoh and mawar) and S. affinis (var. kalimantan) to study the diversity of flower-visiting insects.

\section{Observation of Visiting Insect Diversity}

The diversity of the visiting insects were observed in male flowers of Pondoh, Mawar, and Kalimantan salacca (Fig. 1) in Mekarsari Fruits Garden from February to March 2015. Visiting insects diversity was observed by using the fixed sample method (Dafni, 1992) in 10 minutes from 9.00-11.00 am and 1.00-3.00 pm on sunny days for fifteen days (6 days in two weeks in February and 9 days in three weeks in March). The abundance and species composition of floral insect visitors were measured. Some individuals of each insect species were captured using an insect net and then put inside a jar containing ethyl acetate. The specimens were preserved through the drying method (Borror et al., 1989). During the observation of the insect diversity, the air temperature and humidity of the study site also were measured.

\section{Identification of Insect Specimens}

The insect specimens were identified based on McAlpine et al. (1981; 1992), Borror et al. (1989), Sakagami and Ohgushi (1990), Lawrence (1991), and Subyanto (1997). The pollinating curculionid species was identified based on Wagiman et al. (2014). The insect specimens were verified at the Entomology Laboratory, Zoology Division, Indonesian Institute of Sciences (LIPI) at Cibinong, West Java, Indonesia.

\section{Pollen Load Measurements}

The pollen load of the three pollinating insects (curculionid beetle, honey bee and stingless bee) were measured. The number of species measured

1: Flowers of salacca: 1 a Pondoh salacca; 1 b Mawar salacca; and 1c Kalimantan salacca 
were 25, 20, and 20 individuals, respectively. Each insect was placed in a microtube containing $0.5 \mathrm{ml}$ of $70 \%$ ethanol: glycerol at $4: 1$. The microtubes were rotated for 24 hours, after which the individual of the insect was removed and the solution centrifuged at $2000 \mathrm{rpm}$ for 10 minutes (Dafni, 1992). The supernatant was removed and $0.1 \mathrm{ml}$ of the remaining solution was shaken till it was homogeneous. This homogeneous solution was dropped onto a Neubauer Improved type hemocytometer and the number of pollens was counted under the light microscope. The number of pollens in one individual insect was calculated by the following formula:

$$
\mathrm{V} 1 / \mathrm{N} 1=\mathrm{V} 2 / \mathrm{N} 2
$$

where

V1 ... volume of four quadrants in a hemocytometer, V2 ... total volume of solution,

$\mathrm{N} 1 \ldots$ number of pollens counted in four quadrants, and $\mathrm{N} 2$... total of pollens load.

\section{Data Analysis}

Data of the visiting insects on the salacca flowers were analyzed using Shannon diversity index $\left(\mathrm{H}^{\circ}\right)$ and evenness (E) in the Paleontological Statistics (PAST) software version 4.4 (Hammer et al., 2001). The similarity of insect composition among salacca varieties was analyzed using Sorensen quantitative index (Magurran, 2004).

\section{RESULTS}

During observation of insect diversity, the air temperature at the study site ranged from $26.6-35.8^{\circ} \mathrm{C}$ with humidity between $65-92 \%$. The visiting insects observed on the Pondoh and Mawar salacca male flowers were 9 species belonging to 6 families and 3 orders. However, the Kalimantan salacca was visited by 5 species belonging to 4 families and 3 orders (Tab. I). The curculionid beetle, Nodocnemis sp. was the main pollinator of Pondoh and Mawar salacca with a visit percentage of $83 \%$ and $88.83 \%$, respectively. Other visiting species consist of A. cerana (6.97\% and 4.85\%), Tetragonula laeviceps (Apidae: Hymenoptera) (Fig. 2) (0.81\% and 0.29\%), Colocasiomyia cf. xanthogaster (Drosophilidae: Diptera) (5.64\% and 3.78\%), Nerius sp. (Neriidae: Diptera) (0.63\% and 0.25\%), Scaptodrosophila sp. (Drosophilidae: Diptera) (0.3\% and $0.17 \%$ ), and Salpingogaster sp. (Syrphidae: Diptera) (0.6\% and 1.12\%), respectively. However, the Nodocnemis sp. did not visit the male flowers of Kalimantan salacca. The potential species as pollinators on Kalimantan salacca were A. cerana, T. laeviceps, and Salpingogaster sp. (50.6\%, 6.8\%, and $11.9 \%$, respectively). The male of Nodocnemis sp. has a smaller body-size (about $2.68 \mathrm{~mm}$ in length) compared with a female $(2.77 \mathrm{~mm})$. Other species of curculionid beetle (Rhabdocnemis maculate) belong to the group of pest insect which damages the flowers, while Vespa affinis (Vespidae: Hymenoptera) belong to predatory insects.

The diversity and evenness of visiting insects on Pondoh and Mawar salacca were low $\left(\mathrm{H}^{\star}=0.72\right.$, $\mathrm{E}=0.23$ and $\mathrm{H}^{`}=0.51, \mathrm{E}=0.19$ ). These low diversity and evenness were caused by the dominance of Nodocnemis sp. in both varieties of salacca, i.e., $83.02 \%$ and $88.83 \%$, respectively. In Kalimantan salacca, the Shannon index was highest $\left(\mathrm{H}^{\star}=1.31\right)$.

I: Diversity of visiting insects on pondoh, mawar, and kalimantan salacca male flowers in Mekarsari Fruit Park, Indonesia

\begin{tabular}{|c|c|c|c|c|c|c|c|c|}
\hline \multirow{2}{*}{ Order } & \multirow{2}{*}{ Family } & \multirow{2}{*}{ Species } & \multicolumn{3}{|c|}{ Number of individuals } & \multicolumn{3}{|c|}{ Percentage (\%) } \\
\hline & & & Pondoh & Mawar & Kalimantan & Pondoh & Mawar & Kalimantan \\
\hline \multirow[b]{2}{*}{ Coleoptera } & \multirow[b]{2}{*}{ Curculionidae } & Nodocnemis sp. & 2752 & 7246 & - & 83.02 & 88.83 & - \\
\hline & & $\begin{array}{l}\text { Rhabdocnemis } \\
\text { maculate }\end{array}$ & 37 & 11 & 41 & 1.12 & 0.13 & 23.3 \\
\hline \multirow{3}{*}{ Hymenoptera } & \multirow{2}{*}{ Apidae } & Apis cerana & 231 & 396 & 89 & 6.97 & 4.85 & 50.6 \\
\hline & & Tetragonula laeviceps & 27 & 24 & 12 & 0.81 & 0.29 & 6.8 \\
\hline & Vespidae & Vespa affinis & 30 & 47 & 13 & 0.9 & 0.58 & 7.4 \\
\hline \multirow{4}{*}{ Diptera } & Syrphidae & Salpingogaster sp. & 20 & 91 & 21 & 0.6 & 1.12 & 11.9 \\
\hline & Neriidae & Nerius sp. & 21 & 20 & - & 0.63 & 0.25 & - \\
\hline & \multirow[b]{2}{*}{ Drosophilidae } & Scaptodrosophila sp. & 10 & 14 & - & 0.3 & 0.17 & - \\
\hline & & $\begin{array}{l}\text { Colocasiomyia cf } \\
\text { xanthogaster }\end{array}$ & 187 & 308 & - & 5.64 & 3.78 & - \\
\hline \multicolumn{3}{|c|}{ Number of individuals (N) } & 3315 & 8157 & 176 & - & - & - \\
\hline \multicolumn{3}{|c|}{ Number of species (S) } & 9 & 9 & 5 & - & - & - \\
\hline \multicolumn{3}{|c|}{ Shannon diversity index (H') } & 0.72 & 0.51 & 1.31 & - & - & - \\
\hline \multicolumn{3}{|c|}{ Evenness index (E) } & 0.23 & 0.19 & 0.74 & - & - & - \\
\hline
\end{tabular}




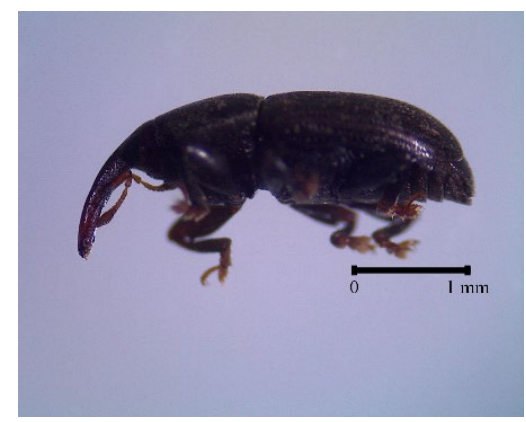

$2 \mathrm{a}$

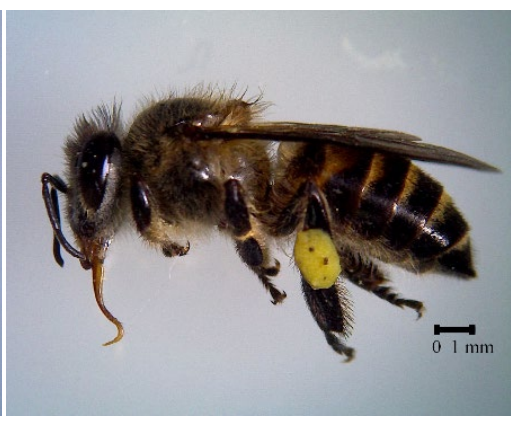

$2 \mathrm{~b}$

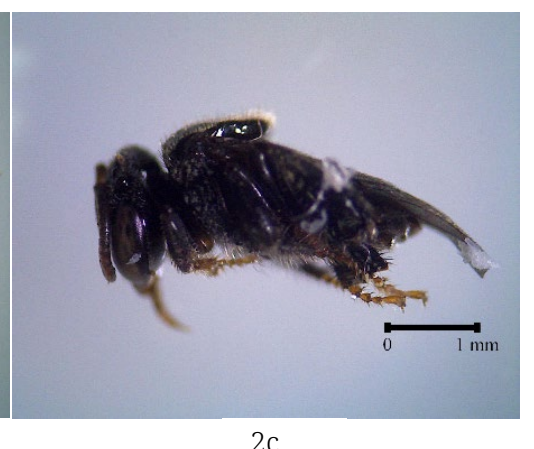

$2 \mathrm{c}$

2: Three dominant insect species as pollinators of salacca: 2 a Nodocnemis sp.; $2 b$ Apis cerana; and 2c Tetragonula laeviceps

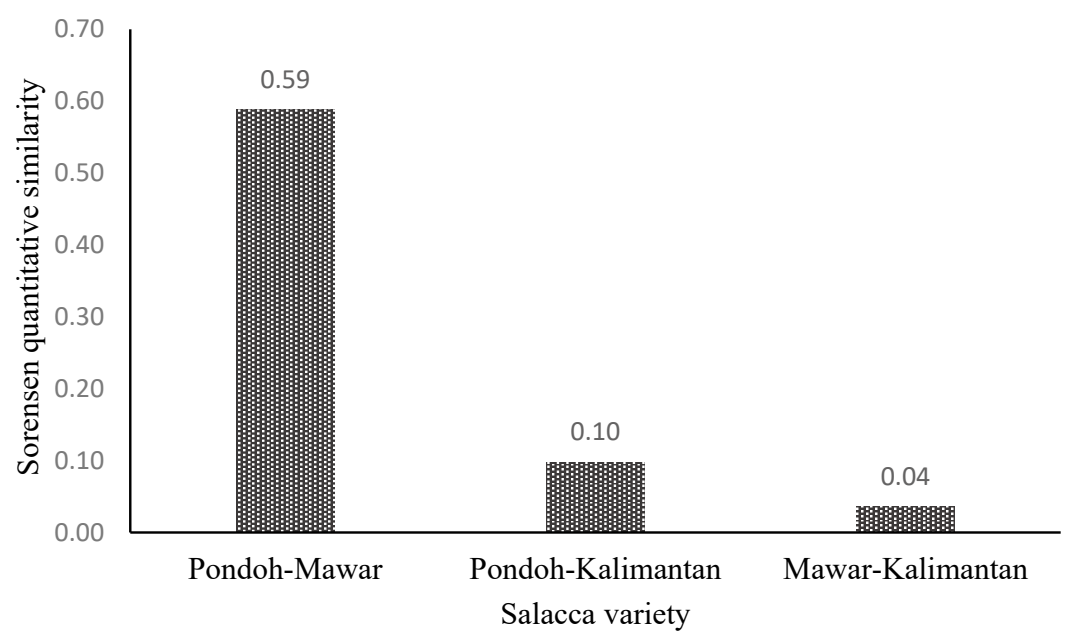

3: Sorensen quantitative similarity of visiting insect species between Pondoh-Mawar, Pondoh-Kalimantan, and Mawar-Kalimantan salacca

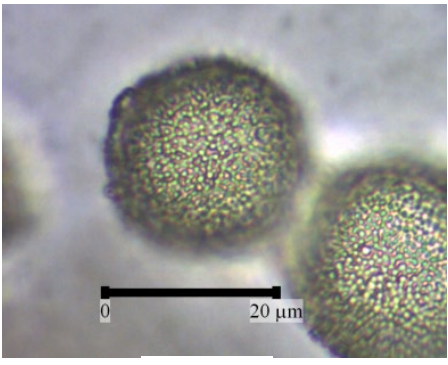

$4 \mathrm{a}$

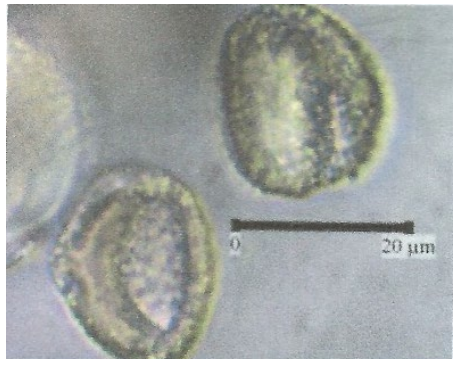

$4 \mathrm{~b}$

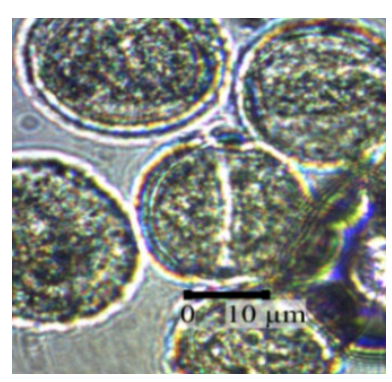

$4 \mathrm{c}$

4: Pollens of salacca: 4a Pondoh salacca; 4 b Mawar salacca, and 4c Kalimantan salacca

The individual number of each species showed highly even $(E=0.74)$ and no dominant species was found. The similarity of species composition was highest in Pondoh-Mawar salacca $(S N=0.59)$ compared to Pondoh-Kalimantan $(\mathrm{SN}=0.10)$, and Mawar-Kalimantan (SN = 0.04) (Fig. 3).

The pollen of salacca is around $20 \mu \mathrm{m}$ in diameter (Fig. 4). The average pollen load on Nodocnemis sp. were about 129 pollen grains (male) and 127 pollen grains (female). However, the pollen load on A. cerana, and T. laeviceps were 7893 and 4228 pollen grains, respectively (Fig. 5).

\section{DISCUSSION}

The male inflorescence of salacca is in the range of $10-15 \mathrm{~cm}$ in length. Male flowers are usually reddish and arranged as tile-like and suitable for foraging of pollinating insects which allow for pollination. The dominant insects found on the male flowers of pondoh and mawar salacca were Nodocnemis sp., A. cerana and C. cf xanthogaster, respectively. However, in Kalimantan salacca the dominant visiting insects were Hymenoptera, Coleoptera and Diptera, and bees (A. cerana and T. laeviceps) were as potential pollinators. Nodocnemis sp. visited the Pondoh and Mawar 

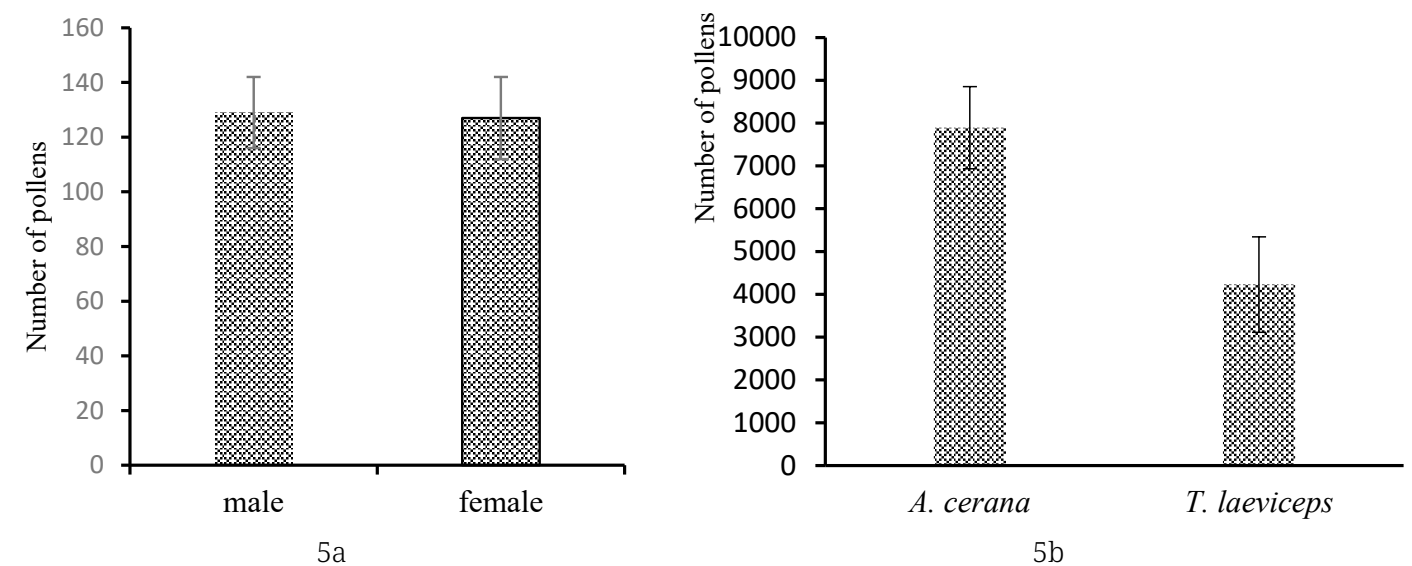

5: The average of pollen load of salacca on: 5 a Nodocnemis sp.; $5 b$ Apis cerana and Tetragonula laeviceps. Standart error is shown in each bar

salacca during the day. The beetle species was also reported as the dominant pollinator of Pondoh salacca at Sleman, Yogyakarta (Mogea, 1978). In this study, we didn't found Nodocnemis sp. on Kalimantan salacca flowers. Similarly, the beetle species was absent on Bali salacca (Salacca zalacca var. amboinensis) (Darmadi et al., 2002). This could be due to the chemical composition in Kalimantan and Bali varieties which might be repellent to the beetle.

The results also showed that honey bee, A. cerana foraged on the three varieties of salacca (Pondoh, Mawar and Kalimantan). Bees are potential pollinating insects on most crops related to their foraging activity (Michener, 2000). Environmental parameters affect the foraging activity of A. cerana (Faheem et al., 2004). The foraging activities of honey bees are high in a temperature range of $26-34{ }^{\circ} \mathrm{C}$ (Amano et al., 2000). Apis cerana is a social insect with hundreds to thousands of individuals in the colony. Worker bees actively looking for pollen and nectar for their colony needed. During foraging, the pollens are loaded in the corbicula of the hind legs. Moreover, previous studies reported that the honey bees as the main pollinators in the agricultural landscape (Kremen et al., 2002), such as in chili (Raw, 2000), jatropha (Atmowidi et al., 2008), sunflower (Greenleaf et al., 2006), and strawberry (Chang et al., 2001). Stingless bees (T. laeviceps) with small body-size (4-6 cm in length) (Faheem et al., 2004) foraged on salacca flowers. The species also was reported as a pollinator of salacca (Mogea, 1978). Nagamitsu and Inoue (2002) reported in Sarawak, Malaysia, the peak activity of stingless bees was in the morning. Additionally, a previous study showed that T. laeviceps was the main pollinator of plants with small flowers (Michener and Boongird, 2004). This species was also reported as pollinators of Jatropha (Greenleaf et al., 2006), cucumber (Solange et al., 2008), and nutmeg (Dennis, 1994). The wasp, $V$. affinis on the other hand was found to be a predatory insect that hunts for prey on salacca flowers. Matsuura (1988) reported the honey bees were prey to Vespa. Koeniger et al., (1994) reported Vespa foraged on flowers and other locations where honey bees are commonly found.

Syrphid fly, Salpingogaster sp. is another important pollinator of plants (Apituley et al., 2012). This study showed that the species also foraged on Pondoh, Mawar and Kalimantan salacca. This fly was also reported visited flowers of Psilochilus modestus (Orchidaceae) in North America (Pansarin et al., 2008). Another species of fly foraged on salacca flowers was Colocasiomyia cf. xanthogaster (Drosophilidae: Diptera). Similarly, the activities of Colocasiomyia were found on the flowers of Arecaceae, Araceae and Magnoliaceae (Takano et al., 2011). This species was also reported as the pollinator of taro (Okada and Yafuso, 1989; Takano et al., 2012). The bloom of taro flowers produces a strong aroma which attracts Colocasiomyia to lay eggs in the pistil and staminodia. Scaptodrosophila sp. (Diptera) was also visited the flowers of Pondoh and Mawar salacca. This species also visited the flowers of Hibiscus raukensis in Australia (McEvey and Baker, 2001).

The diversity of visiting insects in Pondoh and Mawar salacca was lower than that in Kalimantan salacca. It was caused by one dominant species (Nodocnemis sp.) in Pondoh and Mawar salacca and the similarity of species composition in these varieties was high. Contrary, no dominant species was found in Kalimantan salacca caused a high diversity index. The diversity and abundance of visiting insects were also influenced by environmental parameters, such as temperature, light intensity and humidity. In apple plants, compositions of visiting insects was positively correlated with temperature, but negatively correlated with humidity (Pansarin and Amaral, 2008).

The visiting insects on salacca flowers are also determined by the available pollens as a source of proteins. Pollens also contain vitamins, carbohydrates and fats (Appanah, 1995). Based 
on the aperture, salacca pollens are grouped as monocolpate (Huang, 1972) with about $20 \mu \mathrm{m}$ in diameter. Moreover, pollen load on Nodocnemis sp. was low (127 pollen grains), compared to A. cerana (7,893 pollen grains) and T. laeviceps (4,228 pollen grains). The previous study showed that the pollen load on the three species of stingless bees, i.e., Heterotrigona itama, Lepidotrigona terminata and T. laeviceps were 31392, 23017 and 8015 pollen grains, respectively and the number of pollens attached on the body positively correlated with body weight (Pangestika et al., 2017).

\section{CONCLUSION}

Salacca is a dioecious plant that needs agents of pollination. At least, nine species of insect visit the salacca flowers and three dominant species were Nodocnemis sp., A. cerana and Tetragonula laeviceps as agents of pollination. The salacca pollen load on Nodocnemis sp., A. cerana and T. laeviceps were at least $127,7,893$ and 4,228 pollen grains, respectively.

Acknowledgements

We thank the Head of Mekarsari Fruits Park, Bogor, Indonesia for permission for the research.

\section{REFERENCES}

AMANO, K., NEMOTO, T. and HEARD, T. A. 2000. What are stingless bees and why and how to use them as crop pollinator? A Review JARQ, 34(3): 183-190.

APITULEY, F. L., LEKSONO, A. S. and YANUWIADI, B. 2012. Study on the composition of the insect pollinator of apple plants (Malus sylvestris Mill) in Poncokusumo village, Malang Regency [in Indonesian: Kajian komposisi serangga polinator tanaman apel (Malus sylvestris Mill) di desa Poncokusumo Kabupaten Malang]. El-Hayah, 2: 85-96.

APPANAH, S. and KEVAN, P. G. 1995. Bees in the natural ecosystem. In: The asiatic hive: apiculture, biology, and role in sustainable development in tropical and subtropical asia. Cambridge: Enviroquest, Ltd.

ASHARI, S. 2002. On the agronomy and botany of salak (Salacca zalacca). Ph.D thesis, Wageningen: Wageningen University.

ATMOWIDI, T., RIANTI, P. and SUTRISNA, A. 2008. Pollination effectiveness of Apis cerana Fab. and Apis mellifera Linn. in Jatropha curcas L. (Euphorbiaceae). Biotropia, 15(2): 129-134.

BORROR, D. J., TRIPLEHORN, C. A. and JOHNSON, N. F. 1989. An Introduction to the study of insects. New York: Saunders.

CHANG, D. Y., LEE, M. Y. and MAH, Y. 2001. Pollination on strawberry in the vinyl house by Apis meliferra L. and Apis cerana Fab. Acta Hort., 561: 252-262.

DAFNI, A. 1992. Pollination Ecology: A Practical Approach. New York: Oxford University Press.

DARMADI, A. A. K., HARTANA, A. and MOGEA, J. P. 2002. Flowering of Bali salacca [in Indonesian: Perbungaan salak bali]. Hayati, 9: 59-61.

DENNIS, S. H. 1994. Agricultural Entomology. Oregon: Timber Press.

DOS SANTOS, S. A. B., ROSELINO, A. C. and BEGO, L. R. 2008. Pollination of cucumber, Cucumis sativus L. (Cucurbitales: Cucurbitaceae) by the stingless bees Scaptotrigona aff. depilis Moure and Nannotrigona testaceicornis Lepeletier (Hymenoptera: Meliponini) in greenhouses neotropical. Entomology, 37(5): 506-512.

FAHEEM, M., ASLAM, M. and RAZAQ, M. 2004. Pollination ecology with special reference to insects. J. Res. Sci., 15(4): 395-409.

GARI, N. M. 2005. Studies on Bali salak cultivars (Salacca zalacca var. amboinensis) (Arecaceae). M.Sc. thesis. School of Tropical Biology, James Cook University, Townsville.

GREENLEAF, S. S. and KREMEN, C. 2006. Wild bees enhance honey bee pollination of hybrid sunflower. PNAS., 103(37): 13890-13895.

HAMMER, Ø., HARPER, D. A. T. and RYAN, P. D. 2014. Past: Paleontological statistics software package for education and data analysis. Palaeont. Elect., 4(1): 9.

HUANG, T. C. 1972. Pollen Flora of Taiwan. Taipei: National Taiwan University.

KOENIGER, N., KOENIGER, G. and MARDAN, M. 1994. Mimicking a honeybee queen? Vespa affinis indosinensis P. hunts drones of Apis cerana F. Ethology, 98: 149-153.

KREMEN, C., WILLIAM, M. N. and THORP, R. W. 2002. Crop pollination from native bees at risk from agricultural intensification. PNAS., 99(26): 16812-16819.

LAWRENCE, J. F. and BRITTON, E. B. 1991. The Insects of Australia: A texbook for students and reserch workers. $2^{\text {nd }}$ Edition. Melbourne: Melbourne University Press. 
MAGURRAN, A. E. 2004. Measuring Biological Diversity. Oxford: Blackwell Science.

MATSUURA, M. 1988. Ecological studies on vespine wasps (Hymenoptera: Vespidae) attacking honeybee colonies. Appl. Entomol., 23: 428-440.

MCALPINE, J. F., PETERSON, B. V., SHEWELL, G. E., TESKEY, H. J., VOCKEROTH, J. R., WOOD, D. M. and CURRAN, C. H. 1981. Manual of nearctic Diptera. Volume 1. Ontario: Canadian Government Publishing Centre Supply and Services Canada Hull.

MCALPINE, J. F., PETERSON, B. V., SHEWELL, G. E., TESKEY, H. J., VOCKEROTH, J. R. and WOOD, D. M. 1992. Manual of nearctic Diptera. Volume 2. Ontario: Canada Communication Group-Publishing.

MCEVEY, S. F. and BARKER, J. S. F. 2001. Scaptodrosophila aclinata: a new Hibiscus flower-breeding species related to S. hibisci (Diptera: Drosophilidae). Rec. Austral. Mus., 53(2): 255-262.

MICHENER, C. D. 2000. The bees of the world. Baltimore: The John Hopkins Univ Press.

MICHENER, C. D. and BOONGIRD, S. 2004. A new Species of Trigona from Peninsular Thailand (Hymenoptera: Apidae: Meliponini). J Kan. Entomol. Soc., 77: 143-146.

MOGEA, J. P. 1982. Salacca zalacca, the correct name for the salak palm. Principes, 26(2): 70-72.

MOGEA, J. P. 1980. The Flabellate-leaved species of salacca (Palmae). Reinwardtia, 9: 461-479.

MOGEA, J. P. 1978. A new species in the genus Salacca. Principes, 22(2): 56-63.

NAGAMITSU, T. and INOUE, T. 2002. Foraging activity and pollen diets of subterranean stingless bee colonies in response to general flowering in Serawak, Malaysia. Apidologie, 33: 303-314.

OKADA, T. and YAFUSO, M. 1989. The genus Colocasiomyia DUDA (Diptera, Drosophilidae) from Sulawesi. Proc. Japn. Soc. Syst. Zool., 39: 48-55.

PANSARIN, E. R. and AMARAL, M. C. E. 2008. Pollen and nectar as a reward in the basal epidendroid Psilochilus modestus (Orchidaceae: Triphoreae): a study of floral morphology, reproductive biology and pollination strategi. Flora, 203: 474-483.

PENGESTIKA, N. W., ATMOWIDI, T. and KAHONO, S. 2017. Pollen load and flower constancy of three species of stingless bees (Hymenoptera, Apidae, Meliponinae). Trop. Life Sci. Res., 28(2): 179-187.

RAW, A. 2000. Foraging behaviour of wild bees at hot pepper flower (Capsicum annum) and its possible influence on cross pollination. Ann. Bot., 85: 487-492.

TANJUNG, S. R., DAHELMI and MAIRAWITA. 2019. The activity of insect visitors of salacca flowers (Salacca sumatrana Becc.) in South Tapanuli Regency [in Indonesian: Aktivitas serangga pengunjung pada bunga salak (Salacca sumatrana Becc.) di Kabupaten Tapanuli Selatan]. J. Edu. Develop., 7: 233-235.

SAKAGAMI, S. F., OHGUSHI, R. and ROUBICK, D. W. 1990. Natural history of social wasps and bees in equatorial Sumatera. Sapporo: Hokkaido University Press.

SCHUILING, D. L. and MOGEA, J. P. 1991. Salacca zalacca (Gaertner) Voss. In: Edible fruits and nuts. Wageningen: Plant Resources of South-East Asia 2. Pudoc.

SUBYANTO and SULTHONI, A. 1997. Insect determination key [in Indonesian: Kunci Determinasi Serangga]. Yogyakarta: Kanisius.

SUDARYONO, T., PURNOMO, S. and SOLEH, M. 1993. Cultivar distribution and estimation of area development of Salacca. Penel. Hort., 5: 1-4.

SUSKENDRIYATI, H., ARTA, W., NUR, H. and DEWI, C. 2000. Morphological studies and the relationship between Pondoh salacca (Salacca zalacca (Gaert.) Voss.) varieties in Sleman highlands [in Indonesian: Studi morfologi dan hubungan kekerabatan varietas salak pondoh (Salacca zalacca (Gaert.) Voss.) di dataran tinggi Sleman]. Biodiversitas, 1(2): 59-64.

TAKANO, K. T., REPIN, R., MOHAMED, M. B. and TODA, M. J. 2012. Pollination mutualism between Alocasio macrorrhizos (Araceae) and two taxonomically undescribed Colocasiomyia species (Diptera: Drosophilidae) in Sabah, Borneo. Plant Biology, 14(4): 555-564.

TAKANO, K. T., SUWITO, A., GAO, J. J. and YIN, J. T. 2011. Molecular phylogeny of the cristata species group of the genus Colocasiomyia (Diptera: Drosophilidae). Low. Temp. Sci., 69: 19-28.

WAGIMAN, F., EFENDI, F. and HARJAKA, T. 2014. Impact of Merapi eruption in 2010 on pollinator insect of Salacca flower. J. Perl. Tan. Indon., 8: 3-16.

Contact information

Tri Atmowidi: atmowidi@apps.ipb.ac.id 
